\title{
HAKEKAT KEMANUSIAAN DAN PENGEMBANGANNYA DALAM PENDIDIKAN ISLAM
}

\author{
Oleh : Dr. Hj. Ida Umami., M.Pd.Kons
}

\begin{abstract}
This research generally aims to get brief description of teachers' understanding aboutnstudents and its implication in learning process. Specifically, the purpose of this research are to get description about: 1) teachers understanding about students and its defferences among variables, 2) the implementation of high touch unsure in learning process according to teachers' and students and defferences among them, 3) the contribution of teachers, understanding about student toward high touch applied in learning process and, the different response between teachers and students about high touch implementation. This research is conducted by descriptive quantitative method. The population is all teachers and students at senior high school in Padang. Samples are taken by using stratified cluster random sampling technique. The percentage, correlation and test. The results of this research reveal that: 1) everall, teachers understanding is in middle category, so is with the implementation toward learning process, 2) five observable variables about the nature of man are valid and can be used to explain teachers' understanding about the nature of man as laten variable, and six observable variables about high touch implementation as implication of teachers' understanding about student in learning process. Therefore, teachers understanding about student has positive and significant correlation with implementation of teachers' understanding about nature of man toward learning process trough high touch implementation, and 3) teachers' opinion about high touch implementation as implication of teachers' understanding toward learning process differ significantly with students' opinion. In general, teachers' opinion score is higher compared with student's opinion score
\end{abstract}

Kata Kunci: Pemahaman dan Persepsi Pendidik, Hakekat Kemanusiaan, Lingkungan Psikologis dalam Pembelajaran

\section{Pendahuluan}

Allah SWT menciptakan manusia dengan harkat dan martabat kemanusiaan yang tinggi. Harkat dan martabat manusia mencakup: hakekat manusia yang meliputi manusia sebagai makhluk: paling sempurna, paling tinggi derajatnya, makhluk yang bertaqwa dan pemilik hak asasi manusia; dimensi kemanusiaan meliputi dimensi: kefitrahan, keindifidualan, kesosialan, kesusilaan dan dimensi keberagamaan; dan pancadaya meliputi daya: taqwa, cipta, rasa, karsa dan karya. Apabila harkat dan martabat manusia ini dikembangkan, maka manusia akan mencapai derajat kemuliaan yang tinggi sesuai dengan tujuan penciptaannya. Pendidikan dimaksudkan untuk mengembangkan dan melatih banyak segi potensi pribadi peserta didik, meliputi hakekat kemanusiaan, dimensi dan pancadayanya dalam proses pembelajaran.

Proses pembelajaran, pada dasarnya tidak dapat dilepaskan dari pemahaman pendidik tentang peserta didiknya. Hal ini dikarenakan pandangan pendidik terhadap peserta didik tersebut akan mendasari pola pikir dan perlakuan yang diberikan kepada peserta didiknya. Pembelajaran merupakan suatu proses yang kompleks, sebab dalam setiap pembelajaran peserta didik 
tidak sekedar menyerap informasi dari pendidik, tetapi melibatkan potensinya dalam melaksanakan berbagai kegiatan maupun tindakan yang harus dilakukan, terutama bila diinginkan hasil belajar yang baik, yaitu hasil belajar yang bermakna, komprehensif, dan berguna dalam kehidupan peserta didik.

Pemahaman pendidik tentang peserta didik yang benar akan tercermin dalam program pendidikan yang fokus pada pengembangan segenap potensi peserta didik. Pengembangan itu mencakup keseluruhan hakekat dan dimensi kemanusiaan serta pancadaya yang dimiliki peserta didik melalui teraplikasikannya lingkungan psikologis pembelajaran yang mencakup: pengakuan, kasih sayang dan kelembutan, penguatan, tindakan tegas yang mendidik, pengarahan dan keteladanan (high-touch) di samping high-tech dalam setiap proses pembelajaran yang diselenggarakannya. Sebaliknya, pendidik yang kurang memahami peserta didik akan menyebabkan terjadi praktik-praktik pembelajaran yang kurang memberikan kemungkinan terhadap pengembangan potensi peserta didik. Akibatnya potensi peserta didik akan terabaikan, tersiasiakan dan bahkan mungkin terdholimi. Sebab, kewibawaan pendidik yang meliputi unsur pengakuan, kasih sayang dan kelembutan, pengarahan, penguatan dan tindakan tegas yang mendidik serta keteladanan tidak teraplikasikan dalam proses pembelajaran.

Di sekolah, disinyalir masih banyak pendidik yang belum memahami dan mengetahui hakekat peserta didik secara baik dan benar. Akibatnya dalam proses pembelajaran, belum sepenuhnya terlihat adanya internalisasi nilai-nilai yang terkandung dalam materi pelajaran dalam usaha pengembangan potensi yang dimiliki peserta didik yang mencakup berbagai dimensi kemanusiaan dan pancadaya mereka. Kenyataan ini dapat terlihat pada adanya perlakuanperlakuan yang kurang mendidik dari pendidik terhadap peserta didik, antara lain, membentak di depan umum, melabeli dengan gelar yang buruk, seperti Si Bodoh, Si Tolol dan sebagainya. Hasil penelitian yang dilakukan Robinson (1986:191) menyimpulkan bahwa pemberian label kepada peserta didik di sekolah memiliki pengaruh yang kuat terhadap keberhasilan atau kegagalan peserta didik. ${ }^{1}$ Label yang buruk akan menyebabkan peserta didik identik dengan label yang diberikan. Sedangkan label yang baik akan meningkatkan harapan yang besar bagi peserta didik untuk meraih keberhasilan.

Tindakan-tindakan pendidik yang kurang memahami hakekat peserta didik tersebut pada akhirnya, mengakibatkan peserta didik merasa kurang dihargai. Hal itu, menimbulkan kondisi yang kurang kondusif dalam belajar dan kurang memberikan kemungkinan terhadap terkembangkannya seluruh potensi yang dimiliki oleh peserta didik, akan tetapi, malahan akan cenderung mematikannya.

1 Robinson, Philip. 1986. Beberapa Prespektif Sosiologi Pendidikan, (penerjemah: Hasan Basri. Jakarta: Rajawali

RI'AYAH, Vol. 01, No. 02 Juli-Desember 2016 
Hasil penelitian yang dilaksanakan oleh Made Pidarta (1996) tentang pengembangan afeksi dalam proses pembelajaran menyimpulkan bahwa masih diperlukannya peningkatan pemahaman pendidik tentang hakekat manusia yang melekat pada diri peserta didik. ${ }^{2}$ Sehingga pendidik dapat menghormati harkat dan martabat peserta didik melalui pengembangan afeksi belajar yang menyatu dengan pengembangan kognitif dan psikomotorik pada diri peserta didik dalam proses pembelajaran sehari-hari, sebab pemahaman pendidik terhadap peserta didik dipandang sebagai unsur yang penting dan menentukan keberhasilan pencapaian tujuan pembelajaran.

Berdasarkan fenomena sebagaimana dipaparkan di atas, dirasakan mendesak adanya usaha yang mengarah kepada perbaikan pemahaman pendidik terhadap hakekat kemanusiaan peserta didik secara memadai khususnya dan orientasi pendidikan pada umumnya. Dengan pemahaman penuh pendidik terhadap hakekat peserta didik, proses pembelajaran dalam upaya pencapaian tujuan pendidikan akan dapat diwujudkan seirama dengan segenap potensi yang dimiliki peserta didik yang dikenal baik oleh pendidik.

Berdasarkan paparan latar belakang masalah di atas, maka masalah penelitian adalah bagaimana tingkat pemahaman dan persepsi pendidik tentang lingkungan psikologis dalam pembelajaran yang mencakup pengakuan, kasih sayang dan kelembutan, penguatan, tindakan tegas yang mendidik, pengarahan dan keteladanan (high Touch) dan bagaimana aplikasi pemahaman pendidik tentang peserta didik dalam proses pembelajaran melalui penerapan high touch menurut pendidik dan peserta didik serta perbedaannya antar variabel, yaitu variabel kelas, sekolah dan jenis kelamin serta bagaimana profil aplikasi pemahaman pendidik tentang peserta didik dalam proses pembelajaran melalui penerapan high touch.

Secara umum penelitian ini bertujuan untuk memperoleh gambaran berkenaan dengan pemahaman pendidik tentang peserta didik dan aplikasinya dalam proses pembelajaran. Secara khusus penelitian ini bertujuan untuk mendapatkan gambaran tentang tingkat pemahaman pendidik tentang peserta didik, aplikasi pemahaman pendidik tentang peserta didik dalam proses pembelajaran melalui penerapan high touch menurut pendidik dan peserta didik serta perbedaannya antar variabel, yaitu variabel kelas, sekolah dan jenis kelamin, sumbangan pemahaman pendidik tentang peserta didik terhadap aplikasi penerapan high touch dalam proses pembelajaran dan profil aplikasi pemahaman pendidik tentang peserta didik dalam proses pembelajaran melalui penerapan high touch.

Hasil penelitian ini diharapkan bermanfaat bagi kepala sekolah dalam meningkatkan kualitas pendidik dalam proses pembelajaran, terutama berkenaan dengan pemahaman pendidik/pendidik tentang hakekat peserta 
didik, sehingga proses pembelajaran tersebut menumbuhkan suasana yang memungkinkan peserta didik untuk dapat mengembangkan segenap dimensi kemanusiaan dan pancadaya sesuai dengan harkat dan martabat kemanusiaannya.

Hasil penelitian juga diharapkan bermanfaat bagi pendidik dalam meningkatkan wawasan, pengetahuan, keterampilan, dan sikap berkenaan dengan pemahamannya tentang hakekat kemanusiaan dan aplikasinya dalam proses pembelajaran khususnya dalam penciptaan lingkungan psikologis pembelajaran yang mencakup: pengakuan, kasih sayang dan kelembutan, penguatan, tindakan tegas yang mendidik, pengarahan dan keteladanan (hightouch), sehingga setiap proses pembelajaran tersebut diwarnai dengan penghargaan yang tinggi terhadap peserta didik sesuai dengan hakekat kemanusiaannya.

Penelitian ini bersifat deskriptif karena menggambarkan kondisi pemahaman pendidik terhadap peserta didik. Di samping itu penelitian ini juga bersifat korelasional karena melihat hubungan antara pemahaman guru terhadap peserta didik dengan implikasi pemahaman tersebut dalam proses pembelajaran.

Populasi dalam penelitian ini adalah seluruh guru dan siswa Kelas 1 dan Kelas 2 IPA dan IPS SMA Negeri Kota Padang. Sampel diambil dengan teknik stratified cluster random sampling. Penarikan sampel dalam penelitian ini dilakukan melalui dua tahap. Tahap pertama adalah mengidentifikasi sampel berdasarkan strata sekolah dan dilanjutkan dengan tahap kedua yaitu penentuan sampel berdasarkan kelas, dengan mengikuti langkah yang dikemukakan oleh Cochran (1977). ${ }^{3}$

Sampel penelitian ini adalah SMA Negeri 1 Padang untuk kategori/kelompok tinggi, SMA Negeri 5 Padang untuk kelompok sedang dan SMA Negeri 13 Padang untuk kelompok rendah. Sedangkan guru diambil 8 orang dari masing-masing kelas yang menjadi sampel penelitian yang keseluruhannya berjumlah 72 0rang.

Variabel dalam penelitian ini ada dua yaitu variabel laten pemahaman pendidik tentang peserta didik dengan lima observable variabels yakni: manusia sebagai makhluk yang sempurna, makluk yang tertinggi derajatnya, makhluk yang bertaqwa, makhluk menjadi khalifah di bumi dan makhluk pemilik hak asasi manusia (HAM) dan variabel laten aplikasi pemahaman guru melalui penciptaan lingkungan psikologis dalam pembelajaran dengan enam observable variabels yang mencakup: pengakuan, kasih sayang dan kelembutan, penguatan, tindakan tegas yang mendidik, pengarahan dan keteladanan (high-touch).

\section{Press}

${ }^{3}$ Cohran, William G. 1991. Teknik Penarikan Sampel (penerjemah: Rudiansyah). Jakarta: UI

RI'AYAH, Vol. 01, No. 02 Juli-Desember 2016 
Instrumen penelitian ini adalah angket dan dokumentasi. Angket digunakan untuk mengumpulkan data primer berkenaan dengan pemahaman pendidik tentang peserta didik dan implikasinya terhadap proses pembelajaran. Angket penelitian ini disusun dalam bentuk semantik differensial. Sedangkan dokumentasi digunakan untuk memperoleh data skunder berkaitan dengan pelaksanaan proses pembelajaran di sekolah

Pengumpulan data dilakukan langsung oleh peneliti sendiri terhadap seluruh sampel yang telah ditentukan dalam penelitian ini. Data penelitian diperoleh melalui angket yang kemudian dianalisis dengan prosentase, korelasi dan $t$ tes. Untuk mengetahui tingkat pencapaian responden pada masing-masing variabel digunakan + 2 SD untuk kategori baik, + 1 SD untuk kategori cukup, mean untuk kategori sedang, - 1 SD untuk kategori kurang dan - 2 SD, untuk kategori cukup.

\section{Kajian Teori}

Proses pembelajaran, pada dasarnya, tidak dapat dilepaskan dari pemahaman guru tentang peserta didiknya. Hal ini dikarenakan pandangan guru terhadap peserta didik tersebut akan mendasari pola pikir dan perlakuan yang diberikan kepada siswa. Konsep pembelajaran menurut Covey (1997) adalah suatu proses di mana lingkungan secara disengaja dikelola untuk memungkinkannya turut serta dalam tingkah laku tertentu dalam kaitannya dengan pencapaian tujuan pembelajaran ${ }^{4}$. Proses pembelajaran dalam upaya pencapaian tujuan tersebut, sangat dipengaruhi tipe/gaya guru dalam melaksanakan proses pembelajaran (Ballantine, 1983:189). ${ }^{5}$ Guru memiliki posisi dan peran yang strategis dalam meningkatan kualitas proses pembelajaran di kelas. Peran tersebut antara lain dapat dilakukan melalui pengoptimalan segenap kompetensi pribadi dalam melakukan perubahan untuk penyelenggaraan proses pembelajaran yang lebih baik (Fulan, G Michael (1993:118). ${ }^{6}$ Kepribadian guru yang baik, tercermin dari gayanya melaksanakan proses pembelajaran yang efektif. Guru yang efektif antara lain ditandai dengan lima pokok karakter perilaku yaitu kejelasan dalam memberikan materi pelajaran, menguasai teknik penyampaian materi, berorientasi kepada perkembangan siswa, menekankan kepada proses pembelajaran (keaktifan siswa), dan berorientasi pada kesuksesan siswa.

Pemahaman guru tentang peserta didik yang benar akan tercermin dalam pengembangan segenap potensi siswa peserta didik. Pengembangan itu mencakup keseluruhan dimensi kemanusiaan siswa melalui terciptanya

\footnotetext{
${ }^{4}$ Corey, Gerald. .1986. Teori dan Praktik Konseling dan Psikoterapi. Bandung: Eresco.

5 Ballantine, Jeanne H. 1983. The Sociology of Education, A Systematic Analysis. New Jersey: Prentice-Hall.

6 Fulan, G Michael. 1993. The New Meaning of Educational Change. NewYork: Teacher College Press.
}

RI'AYAH, Vol. 01, No. 02 Juli-Desember 2016 
lingkungan psikologis dalam pembelajaran dengan enam observable variabels yang mencakup: pengakuan, kasih sayang dan kelembutan, penguatan, tindakan tegas yang mendidik, pengarahan dan keteladanan (high-touch), di samping high-tech dalam setiap proses pembelajaran yang diselenggarakannya (Pokja Pengembangan Peta Keilmuan Pendidikan, 2005).7 Sebaliknya, guru yang kurang memahami peserta didik akan menyebabkan terjadi praktekpraktek pembelajaran yang kurang memberikan kemungkinan terhadap pengembangan potensi peserta didik. Akibatnya peserta didik akan terabaikan, tersia-siakan dan bahkan mungkin terdholimi. Sebab, kewibawaan (high-touch) yang meliputi unsur pengakuan, kasih sayang dan kelembutan, pengarahan, penguatan dan tindakan tegas yang mendidik serta keteladanan, tidak teraplikasikan dalam proses pembelajaran (Prayitno., dkk. 2005). ${ }^{8}$

Pendidik dituntut tanggung jawabnya untuk melaksanakan proses pembelajaran secara profesional, yaitu praktik pendidikan yang didasarkan pada kaidah-kaidah keilmuan pendidikan. Esensi permasalahan peningkatan profesionalisme pendidikan menurut Winarno (2005) adalah masalah akuntabilitas pendidik. Ia melontarkan sinisme bahwa praktik pendidikan yang dilaksanakan oleh pendidik di sekolah tidak didasari oleh ilmu pendidikan atau "pentip" (pendidikan-tanpa-ilmu pendidikan). ${ }^{9}$

Pendidik secara leluasa "mementip" peserta didik dalam proses pembelajaran tanpa dasar ilmu pendidikan yang kuat atau bahkan tidak dimiliki sama sekali. Praktik pendidikan yang demikian ini, tentu saja tidak dapat mengembangkan potensi yang dimiliki peserta didik, dan mungkin bisa merapuhkan dan bahkan mematikannya. "Pentip" dapat menimbulkan berbagai permasalahan belajar dan permasalahan umum lainnya (Hasil penelitian Ida Umami, 2004). ${ }^{10}$ Kenyataan ini diperkuat oleh hasil penelitian Prayitno., dkk (2005) yang mengungkapkan banyaknya permasalahan yang dialami peserta didik terkait dengan proses pembelajaran yang kurang efektif disebabkan pembelajaran yang kurang mengindahkan high touch (human related) tetapi terfokus pada aspek high tech (task-related) saja.

Kelas yang efektif ditunjang iklim sekolah yang memfasilitasi tugas pendidik menjadikan semua ruang kelas sebagai effective classrooms. Mohd Ansyar (2005:1) juga mengemukakan bahwa diperlukan adanya perbaikan yang mendasar pada proses pembelajaran di dalam kelas (classroom change) sesuai

\footnotetext{
7 Pokja Pengembangan Peta Keilmuan Pendidikan. (2005). Peta Keilmuan Pendidikan. Jakarta: Depdiknas Dirjen Dikti.

8 Prayitno, dkk. 2005.. Sosok Keilmuan Ilmu Pendidikan. Padang: Fakultas Ilmu Pendidikan UNP

${ }^{9}$ Winarno Surachmad. 2005. Pendidikan Tanpa Ilmu Pendidikan. Makalah Disampaikan pada Seminar Internasional Pendidikan dan Pertemuan FIP-JIP.

10 Ida Umami.. 2004.. Persepsi Peserta didik tentang Konsep dan Kegiatan Bimbingan dan Konseling. Padang Skolar Jurnal Pendidikan Volume 5, No. 2, Desember 2004.: PPS UNP.
}

RI'AYAH, Vol. 01, No. 02 Juli-Desember 2016 
konsep pembelajaran yang baik. ${ }^{11}$ Sehingga banyak kelas harus berfungsi sebagai basis pembelajaran dari pada sebagai arena pengajaran.

Kenyataan bahwa pendidik sering menampilkan gaya yang kurang disenangi peserta didik seperti pemarah dan cepat emosional, cerewet dan pilih kasih, bertentangan dengan kebutuhan peserta didik yang sangat menginginkan penampilan pendidik yang tidak pemarah/emosional, pendidik yang baik, ramah, pintar dan penuh perhatian. Hubungan yang terjadi antara pendidik dengan peserta didik dalam proses pembelajaran hendaknya terhindar dari gaya/penampilan pendidik yang cenderung memposisikan peserta didik pada kedudukan yang inferior, pasif, lebih menunjukkan pada permusuhan dan pelecehan terhadap kemanusiaan dan potensi yang dimiliki peserta didik. Kondisi negatif dalam hubungan pendidik dengan peserta didik bersifat kontraproduktif terhadap motivasi untuk mendorong peserta didik belajar dengan lebih giat dan lebih berhasil dalam mencapai tujuan pembelajaran. Sebaliknya pembelajaran yang cenderung kurang mengaplikasikan high touch membuat peserta didik kurang bergairah mengikuti pelajaran dalam perwujudan sikap acuh tak acuh terhadap pendidik, tidak mau memperhatikan pelajaran yang disampaikan pendidik, mengantuk, melamun, atau bahkan sengaja menciptakan suasana yang kurang kondusif dalam proses pembelajaran seperti sengaja mengganggu teman, mengejek pendidik, keluar pada waktu pendidik mengajar dan sebagainya. Kondisi sebagaimana digambarkan ini tentu saja tidak akan mendukung terciptanya situasi bagi terwujudnya lingkungan belajar yang kondusif untuk mengoptimalkan pembelajaran, sehingga tujuan yang telah ditetapkan akan sulit untuk dicapai. Hal ini semua tidak serasi dengan penerapan ilmu pendidikan yang konter produktif terhadap upaya untuk mengoptimalkan pembelajaran dan meminimalkan pengajaran.

\section{Hasil Penelitian dan Pembahasan}

Gambaran Data Temuan Penelitian

Berdasarkan hasil pengolahan data, temuan penelitian dapat dipaparkan sebagaimana Tabel 1, 2, dan 3 berikut:

11 Mohd. Ansyar. 1989. Dasar-Dasar Pengembangan Kurikulum. Jakarta: Depdikbud Dirjen Dikti.

RI'AYAH, Vol. 01, No. 02 Juli-Desember 2016 
Tabel 1. Statistik Deskriptif data Pemahaman Pndidik terhadap Peserta Didik

\begin{tabular}{|c|c|c|c|c|c|}
\hline & $\begin{array}{l}\text { Pemahaman } \\
\text { Guru SMA N } 1\end{array}$ & $\begin{array}{l}\text { Pemahaman } \\
\text { Guru SMA N } 5\end{array}$ & $\begin{array}{c}\text { Pemahaman } \\
\text { Guru SMA N } \\
13\end{array}$ & Keseluruhan \\
\hline \multirow[t]{2}{*}{$\mathrm{N}$} & Valid & 24 & 24 & 24 & 72 \\
\hline & Missing & 0 & 0 & 0 & 0 \\
\hline \multicolumn{2}{|c|}{ Mean } & 435.3750 & 427.6250 & 422.2083 & 428.4028 \\
\hline \multicolumn{2}{|c|}{ Median } & 429.5000 & 434.0000 & 427.0000 & 429.5000 \\
\hline \multicolumn{2}{|c|}{ Mode } & 427.00 & 423.00 & 423.00 & 423.00 \\
\hline \multicolumn{2}{|c|}{ Std. Deviation } & 33.65530 & 42.43953 & 33.76901 & 36.73416 \\
\hline \multicolumn{2}{|c|}{ Variance } & 1132.67935 & 1801.11413 & 1140.34601 & 1349.39887 \\
\hline \multicolumn{2}{|c|}{ Range } & 143.00 & 142.00 & 139.00 & 157.00 \\
\hline \multicolumn{2}{|c|}{ Minimum } & 360.00 & 353.00 & 346.00 & 346.00 \\
\hline \multicolumn{2}{|c|}{ Maximum } & 503.00 & 495.00 & 485.00 & 503.00 \\
\hline \multicolumn{2}{|c|}{ Sum } & 10449.00 & 10263.00 & 10133.00 & 30845.00 \\
\hline
\end{tabular}

Tabel 2. Statistik Deskriptif data Implementasi High Touch dalam Proses Pembelajaran Menurut Guru

\begin{tabular}{|c|c|c|c|c|c|}
\hline & $\begin{array}{c}\text { Implementasi } \\
\text { Guru SMA N } \\
1\end{array}$ & $\begin{array}{c}\text { Implementasi } \\
\text { Guru SMA N } 5\end{array}$ & $\begin{array}{c}\text { Implementasi } \\
\text { Guru SMA N } \\
13\end{array}$ & $\begin{array}{c}\text { Implementa } \\
\text { si Guru } \\
\text { Gabungan }\end{array}$ \\
\hline \multirow[t]{2}{*}{$\mathrm{N}$} & Valid & 24 & 24 & 24 & 72 \\
\hline & Missing & 0 & 0 & 0 & 0 \\
\hline \multicolumn{2}{|c|}{ Mean } & 451.6667 & 448.1250 & 442.2500 & 443.8056 \\
\hline \multicolumn{2}{|c|}{ Median } & 451.5000 & 456.5000 & 433.0000 & 441.5000 \\
\hline \multicolumn{2}{|c|}{ Mode } & 411.00 & 484.00 & 419.00 & 441.00 \\
\hline \multicolumn{2}{|c|}{ Std. Deviation } & 38.75976 & 39.66415 & 33.43423 & 37.04799 \\
\hline \multicolumn{2}{|c|}{ Variance } & 1502.31884 & 1573.24457 & 1117.84783 & 1372.55321 \\
\hline \multicolumn{2}{|c|}{ Range } & 128.00 & 145.00 & 133.00 & 152.00 \\
\hline \multicolumn{2}{|c|}{ Minimum } & 379.00 & 360.00 & 379.00 & 360.00 \\
\hline \multicolumn{2}{|c|}{ Maximum } & 507.00 & 505.00 & 512.00 & 512.00 \\
\hline \multicolumn{2}{|c|}{ Sum } & 10840.00 & 10755.00 & 10614.00 & 31954.00 \\
\hline
\end{tabular}

Tabel 3. Statistik Deskriptif data Implementasi High Touch dalam Proses Pembelajaran Menurut Siswa

\begin{tabular}{|l|l|r|r|r|r|}
\hline & & SMAN 1 & SMAN 5 & SMAN 13 & Gabungan \\
\hline $\mathrm{N}$ & Valid & 131 & 123 & 120 & 374 \\
\hline & Missing & 0 & 0 & 0 & 0 \\
\hline Mean & & 434.2290 & 423.9106 & 410.1250 & 422.755 \\
\hline
\end{tabular}

RI'AYAH, Vol. 01, No. 02 Juli-Desember 2016 


\begin{tabular}{|l|r|r|r|r|}
\hline Median & 429.0000 & 421.0000 & 408.0000 & 419.0000 \\
\hline Mode & 407.00 & 415.00 & 408.00 & 407.00 \\
\hline Std. Deviation & 32.87565 & 33.60377 & 40.09580 & 36.83490 \\
\hline Variance & 1080.8086 & 1129.2132 & 1607.6733 & 1356.81002 \\
& 9 & 5 & 2 & 197.00 \\
\hline Range & 137.00 & 156.00 & 183.00 & 310.00 \\
\hline Minimum & 370.00 & 339.00 & 310.00 & 507.00 \\
\hline Maximum & 507.00 & 495.00 & 493.00 & 158240.00 \\
\hline Sum & 56884.00 & 52141.00 & 49215.00 & \\
\hline
\end{tabular}

Berdasarkan paparan hasil temuan penelitian pada Tabel 1, 2 dan 3 di atas dapat dikemukakan bahwa, berdasarkan ketegori yang telah dikemukakan terdahulu maka dapat dikemukakan bahwa rata-rata pemahaman pendidik terhadap peserta didik masuk dalam kategori sedang. Demikian juga halnya dengan aplikasi pemahaman pendidik tersebut melalui lingkungan psikologis dalam pembelajaran dengan enam observable variabels yang mencakup: pengakuan, kasih sayang dan kelembutan, penguatan, tindakan tegas yang mendidik, pengarahan dan keteladanan (high-touch) dalam proses pembelajaran baik menurut guru maupun menurut siswa masuk pada kategoori sedang.

Pemahaman guru tentang peserta didik memiliki hubungan dengan implikasinya terhadap proses pembelajaran melalui penerapan dan penciptaan lingkungan psikologis dalam pembelajaran dengan enam observable variabels yang mencakup: pengakuan, kasih sayang dan kelembutan, penguatan, tindakan tegas yang mendidik, pengarahan dan keteladanan (high-touch). Secara lebih jelas, besarnya hubungan korelasi (T-value) antara kedua variabel tersebut terangkum dalam gambar sebagai berikut:

RI'AYAH, Vol. 01, No. 02 Juli-Desember 2016 


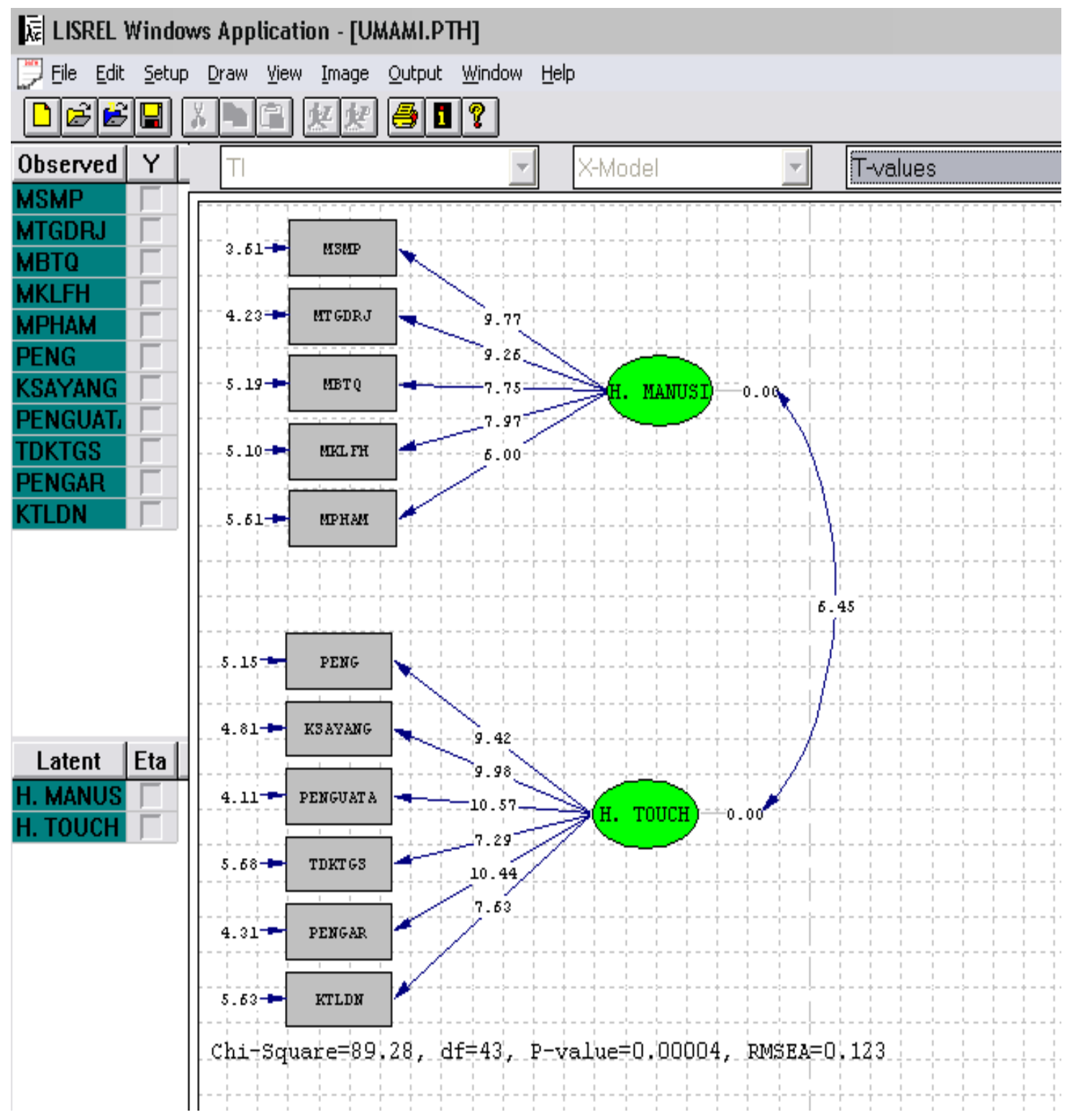

\section{Grafik 1. T Value Hubungan Pemahaman Guru ten tang Siswa dengan Implementasinya Terhadap Proses Pembelajaran Melalui High Touch}

Gambaran data dalam grafik di atas dapat dikemukakan bahwa hakekat manusia (sebagai variabel laten) tidak mungkin diukur secara langsung, yang bisa diukur adalah faktor-faktor karakteristik nya dengan lima peubahan, yaitu:manusia sebagai makhluk yang sempurna, makluk yang tertinggi derajatnya, makhluk yang bertaqwa, makhluk menjadi khalifah di bumi dan makhluk pemilik hak asasi manusia (HAM). Sedangkan aplikasi dalam mewujudkan lingkungan psikologis dalam pembelajaran dapat dilihat melalui enam observable variabels yang mencakup: pengakuan, kasih sayang dan

RI'AYAH, Vol. 01, No. 02 Juli-Desember 2016 
kelembutan, penguatan, tindakan tegas yang mendidik, pengarahan dan keteladanan (high-touch).

\section{Pembahasan}

Berdasarkan paparan hasil penelitian di atas secara umum dapat dikemukakan bahwa pemahaman guru SMA di SMAN Kota Padang masih berada pada kategori sedang. Kondisi pemahaman ini haruslah menjadi perhatian dari semua pihak terkait terutama pihak pimpinan sekolah maupun guru yang bersangkutan untuk dapat mengembangkan lebih lanjut pemahamannya tentang siswa. Hal ini penting mengingat pemahaman ini merupakan instrumental dasar bagi guru dalam melaksanakan tugas dan tanggungjawabnya dalam proses pembelajaran.

Tugas dan tanggungjawab guru yang berat menghendaki adanya pemahaman yang baik terhadap peserta didiknya. Guru memiliki tanggungjawab dalam mengembangkan potensi peserta didik agar mampu kreatif dan dinamis. Agar potensi tersebut dapat berkembang secara serasi dan maksimal, maka peserta didik harus ditinjau kedudukannya sebagai makhluk yang utuh. Utuh sebagai individu (pribadi) dan dalam kaitannya dengan masyarakat.

Tuntutan akan pentingnya pemahaman guru yang baik terhadap siswa ini juga searah dengan tuntutan yang digariskan oleh kode etik guru yang antara lain menghendaki guru berupaya untuk memperoleh informasi tentang peserta didik sebagai bagan melakukan bimbingan dan pembinaan. Selain itu, guru menciptakan suasana sekolah sebaik-baiknya yang menunjang berhasilnya proses pembelajaran.

Pemahaman guru tentang siswa sangat diperlukan dalam pengembangan proses Pemahaman guru ini merupakan salah satu unsur dari kompetensi paedagogik sebagaimana termuat dalam Stándar pendidikan Nasional. Pemahaman guru tentang hakekat manusia secara positip diharapkan membawa pengaruh/dampak yang besar dalam pengembangan interaksi dalam proses pembelajaran.

Hasil penelitian berkenaan dengan pemahaman guru tentang siswa ini juga menghendaki adanya peningkatan pemahaman guru kearah yang lebih baik. Hal ini disebabkan karena tujuan pendidikan itu sendiri sarat dengan hakekat manusia. Oleh karena itu, guru perlu memiliki pemahaman yang benar tentang hakekat manusia. Pemahaman ini penting dan diperlukan berkaitan dengan tugas guru baik sebagai pembimbing maupun pendidik. Pemahaman guru tentang siswa akan berpengaruh terhadap pelaksanaan tugasnya sebagai pembimbing dan pendidik.

Pemahaman yang baik dari para guru terhadap peserta didik akan menghasilkan pemahaman berkenaan hakekat manusia yang mencerminkan harkat dan martabat manusia (HMM), yang mengandung butir-butir bahwa RI'AYAH, Vol. 01, No. 02 Juli-Desember 2016 
manusia adalah: 1) makhluk yang terindah dalam pencitraannya dan paling sempurna, 2) Makhluk yang tertinggi derajatnya, 3) makhluk yang beriman dan bertaqwa, 4) makhluk yang menjadi khalifah di bumi, dan 5) makhluk yang memiliki hak asasi manusia (HAM). Pemahaman ini pada akhirnya akan teraktualisasi dalam pelaksanaan tugasnya menjankan proses pembelajaran melalui penciptaan lingkungan psikologis dalam pembelajaran yang mencakup: pengakuan, kasih sayang dan kelembutan, penguatan, tindakan tegas yang mendidik, pengarahan dan keteladanan (high-touch).

Berdasarkan temuan penelitian berkenaan dengan aplillikasi pemahaman guru tentang siswa terhadap proses pembelajaran di atas, juga dapat dikemukakan bahwa secara umum guru sudah menerapkan kewibawaan atau high touch sebagai implikasi dari pemahamannya terhadap siswa. Penerapan tersebut berada pada kategori sedang. Padahal seharusnya guru dapat menerapkan kewibawaan dengan lebih baik dalam proses pembelajaran, karena kewibawaan merupakan alat pendidikan. Kewibawaan merupakan "alat pendidikan" yang diaplikasikan oleh pendidik untuk menjangkau (to touch) kedirian peserta didik dalam hubungan pendidikan. Kewibawaan ini mengarah kepada kondisi high-touch, dalam arti perlakuan pendidik menyentuh secara positif, konstruktif, dan komprehensif aspek-aspek kedirian/kemanusiaan peserta didik. Kewibawaan meliputi: (1) pengakuan, (2) kasih sayang dan kelembutan, (3) penguatan, (4) pengarahan (5) tindakan tegas yang mendidik, dan 6) keteladanan.

Pemahaman guru terhadap siswa merupakan salah satu kompetensi paedagogik yang harus dimiliki oleh guru. Pemahaman itu memiliki implikasi yang besar dalam proses pembelajaran. Implikasi tersebut dapat diwujudkan guru melalui penerapan kewibawaan (high touch) dalam proses pembelajaran sehingga memungkinkan peserta didik dapat mengembangkan potensinya secara lebih optimal.

Secara umum guru diharapkan menciptakan kondisi yang baik, yang memungkinkan setiap peserta didik dapat mengembangkan kreativitasnya. Proses pembelajaran pada hakekatnya untuk mengembangkan aktivitas dan creativitas peserta didik, melalui berbagai interaksi dan pengalaman belajar. Namur dalam pelaksanaannya seringkali guru kurang menyadari bahwa masih banyak kegiatan pembelajaran yang dilaksanakan justru menghambat aktivitas dan kreativitas peserta didik.

Data temuan penelitian sebagaimana telah dipaparkan pada grafik di atas memberikan gambaran keterkaitan yang erat antar sub-sub variabel penelitian. Data tersebut sekaligus membuktikan bahwa pemahaman guru tentang hakekat menusia berhubungan erat dengan tingkat penerapan kewibawaan atau high touch sebagai implikasi pemahaman guru tersebut dalam proses pembelajaran.

RI'AYAH, Vol. 01, No. 02 Juli-Desember 2016 


\section{Penutup}

Dari hasil penelitian diungkapkan bahwa secara keseluruhan, pendapat guru dan siswa berkaitan dengan aplementasi pemahaman guru tentang siswa terhadap proses pembelajaran pada kategori sedang dan tidak berbeda secara signifikan dari variabel sekolah tetapi signifikan dari variabel jenis kelamin.

Lima observable variabels yakni: manusia sebagai makhluk yang sempurna, makluk yang tertinggi derajatnya, makhluk yang bertaqwa, makhluk menjadi khalifah di bumi dan makhluk pemilik hak asasi manusia (HAM) dinyatakan valid dan dapat menerangkan dengan baik variabel latin pemahaman guru tentang hakekat manusia, enam observable variabels yakni pengakuan, kasih sayang dan kelembutan, penguatan, tindakan tegas yang mendidik, pengarahan dan keteladanan dinyatakan valid dan dapat menerangkan dengan baik variabel latin penciptaan lingkungan psikologis dalam pembelajaran dengan enam observable variabels yang mencakup: pengakuan, kasih sayang dan kelembutan, penguatan, tindakan tegas yang mendidik, pengarahan dan keteladanan (high-touch) sebagai implikasi dari pemahaman guru tentang siswa terhadap proses pembelajaran. Dengan demikian pemahaman guru tentang siswa berkorelasi secara positip dan sangat signifikan dengan imlementasi pemahaman guru tentang hakekat manusia terhadap proses pembelajaran melalui penerapan high touch.

Pendapat guru tentang penerapan high touch sebagai implikasi pemahaman guru terhadap proses pembelajaran berbeda secara sangat signifikan dengan pendapat siswa. Secara umum pendapat guru lebih tinggi dibandingkan dengan pendapat siswa.

\section{Daftar Pustaka}

Ballantine, Jeanne H. (1983). The Sociology of Education, A Systematic Analysis. New Jersey: Prentice-Hall, Inc.

Borich. G.1992. EffectiveTeaching Methods. New York: Merrill.

Cohran, William G. (1991). Teknik Penarikan Sampel (penerjemah: Rudiansyah). Jakarta: UI Press

Covey, Stephen R. (1997). Principle Centered Leadership. Jakarta: Bina Rupa Aksara.

Elliott. N Stephen, Thomas R. Kratochwill, Joan Littelefield, and John F Travers. (1996). Educational Psychology, Effective Teaching, effective Learning. Madison: A Times Miror Company.

Fulan, G Michael. (1993). The New Meaning of Educational Change. NewYork:Teacher College Press.

E. Musyasa. (2007). Menjadi guru profesional menciptakan Pengajaran kreatif dan Menyenangkan. Bandung: PT Remaja Rosda Karya

Imam Barnadib. (1996). Dasar-Dasar Kependidikan, Memahami Makna dan Prespektif Beberapa Teori Pendidikan. Jakarta: Ghalia Indonesia

Made Pidarta. (2000). Landasan Kependidikan. Jakarta: RIneka Cipta.

Novak, Joseph D. (1986). A Theory of Education. London: Cornell University Press

RI'AYAH, Vol. 01, No. 02 Juli-Desember 2016 
Peters, D.G Amstrong, NT Hansen, TV Savace. (1981). Education an Introduction to Teaching. New York: Mcillan Company.

Pokja Pengembangan Peta Keilmuan Pendidikan. (2005). Peta Keilmuan Pendidikan. Jakarta: Depdiknas Dirjen Dikti

Prayitno. (1990). Konselor Masa Depan dalam Tantangan dan Harapan. Padang: Fakultas Ilmu Pendidikan IKIP Padang.

.(2002). Hubungan Pendidikan. Jakarta: Departemen Pendidikan Nasional Direktorat Jendral Pendidikan Dasar dan Menengah Direktorat SLTP.

. (2005.a). Sosok Keilmuan Ilmu Pendidikan. Padang: Fakultas Ilmu Pendidikan UNP.

--------(2005.b) Pendekatan "Basic Need" dalam Pendidikan: Aplikasi Ilmu Pendidikan. Padang: Fakultas Ilmu Pendidikan UNP.

Prayitno dan Erman Amti. (1999). Dasar-Dasar Bimbingan dan Konseling. Jakarta: Rineka Cipta.

Prayitno., dkk. (2005.a). Studi Pengembangan Aplikasi High-Touch dan High-Tech dalam Proses Pembelajaran Di Sekolah. Penelitian Hibah Pascasarjana Tahun Pertama.

, (2005.b). Karakteristik Pendidik dalam Keilmuan Pendidikan. Laporan Penelitian Studi Pengembangan Aplikasi High-Touch dan High-Tech dalam Proses Pembelajaran Di Sekolah. Penelitian Hibah Pascasarjana Tahun Pertama.

Robinson, Philip. (1986). Beberapa Prespektif Sosiologi Pendidikan, (penerjemah: Hasan Basri. Jakarta: Rajawali

Undang-undang Sistem Pendidikan Nasional (SISDIKNAS) No. 20 tahun 2003. 